\title{
Synthesis of Flexible Sulfur-Containing Heteroarotinoids That Induce Apoptosis and Reactive Oxygen Species with Discrimination between Malignant and Benign Cells
}

\author{
Shengquan Liu, ${ }^{\dagger}$ Chad W. Brown, ${ }^{\dagger} \mathrm{K}$. Darrell Berlin, ${ }^{*}, \dagger$ Aridam Dhar, ${ }^{\ddagger}$ Suresh Guruswamy, ${ }^{\ddagger}$ David Brown, ${ }^{\ddagger}$ \\ Ginger J. Gardner $§$ Michael J . Birrer,§ and Doris M. Benbrook*,‡ \\ Department of Chemistry, Oklahoma State University, Stillwater, Oklahoma 74078-3071, Department of Obstetrics \& \\ Gynecology, University of Oklahoma Health Sciences Center, P.O. Box 26901, Oklahoma City, Oklahoma 73190, and Cell and \\ Cancer Biology Department, Center for Cancer Research, National Cancer Institute, 9610 Medical Center Drive, Building C, \\ Rockville, Maryland 20850
}

Received J uly 16, 2003

Regulation of growth, differentiation, and apoptosis by synthetic retinoids can occur through mechanisms that are dependent and independent of their ability to bind and activate nuclear retinoic acid receptors. The objective of this study was to determine if increasing flexibility of the heteroarotinoid structure would affect the specificity of the synthetic retinoids for the receptors and for their regulation of cancerous and nonmal ignant cells. Methods were developed to produce the first examples of heteroarotinoids $\mathbf{1 5 a}-\mathbf{1 5 h}$, which contain urea and/or thiourea linking groups between two aryl rings. Substituents at the para position of the single phenyl ring were either an ester, a nitro group, or a sulfonamide group. Ovarian cancer cell lines Caov-3, OVCAR-3, SK-OV-3, UCI-101, and 222 were utilized, and the inhibitory prowess of the heteroarotinoids was referenced to that of 4-HPR (25). Similar to 4-HPR (25), the heteroarotinoids inhibited growth of all cell lines at micromolar concentrations. Although the heteroarotinoids did not activate retinoic acid receptors, the agents induced potent growth inhibition against the cancer cells with weak activity against normal and benign cells. The growth inhibition was associated with cell loss and induction of reactive oxygen species.

\section{Introduction}

Retinoids (analogues of vitamin A) are known to possess anticancer properties as well as provide useful pharmaceutical responses in the treatment of various other disorders and thus have received considerable scientific attention during the past 2 decades. ${ }^{1}$ Retinoids exhibit their therapeutic properties, at least in part, by interaction with and activation of a specific group of nuclear receptors, termed retinoid receptors. ${ }^{2}$ The retinoid receptors are divided into two distinct types, namely the retinoic acid receptors (RARs) ${ }^{3}$ and the retinoid $X$ receptors $(\mathrm{RXRs}){ }^{4}$ For each type, three receptor subtypes, namely $\operatorname{RAR} \alpha,-\beta$, and $-\gamma$ and $\operatorname{RX} \operatorname{R} \alpha$, $-\beta$, and $-\gamma$, have been identified, for a total of six retinoid receptors. These retinoid receptors belong to the hormone receptor superfamily, and, as a group, this family of proteins regulates the transcription of genes that control a variety of metabolic, developmental, and differentiation pathways. Because the misregulation of any one of these pathways could enhance carcinogenesis, the hormones, or compounds such as retinoids, may regulate these receptors and are therefore potentially chemopreventive agents. ${ }^{5}$

Naturally occurring retinoids trans-retinoic acid (1) and 9-cis-retinoic acid (2) are endogenous ligands for the retinoid receptors and have demonstrated signifi-

* Corresponding authors. For biology (D.M.B.): e-mail, DorisBenbrook@ouhsc.edu. For chemistry (K.D.B.): e-mail, kdb@okstate.edu.

† Oklahoma State University.

₹ University of Oklahoma Health Sciences Center.

$\S$ National Cancer Institute. cant anticancer properties, as has 13-cis-retinoic acid (3). ${ }^{6}$ Some synthetic successor retinoids, such as aroti-

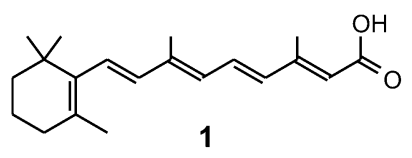<smiles>CC1=C(/C=C/C(C)=C\C=C\C(C)=C\C(=O)O)C(C)(C)CCC1</smiles><smiles>CC1=C(/C=C/C(C)=C/C=C/C(C)=C/C(=O)O)C(C)(C)CCC1(C)C</smiles><smiles>CCOC(=O)/C=C(C)/C=C/C=C(C)/C=C/c1c(C)cc(OC)c(C)c1C</smiles>

noid TTNPB (4) and the clinically employed Etretinate (5), have also shown potent anticarcinogenic characteristics. ${ }^{6}$ However, all of these retinoids have found limited application due to teratogenicity ${ }^{7}$ and/or toxic manifestations such as diarrhea, hair loss, nausea, and headaches. ${ }^{7,8}$ Thus, the study of heteroarotinoids originated $^{9,10}$ as an attempt to mimic the anticarcinogenic action of retinoids, while at the same time reducing unwanted side effects. In fact, several heteroarotinoids have demonstrated reduced toxicity compared to $\mathbf{1}$ and $4^{9 e}$ and, in some examples, exhibited greater anticancer 
activity than selected natural retinoids.9,10 Consequently, heteroarotinoids are currently under extensive investigation for the potential treatment of a variety of disorders. 9,10

Heteroarotinoids such as $\mathbf{6}-\mathbf{1 0}$ constitute a class of synthetic retinoi ds ${ }^{9,10}$ that structurally resemble arotinoids in that at least one aryl moiety is present within the molecular structure. However, heteroarotinoids

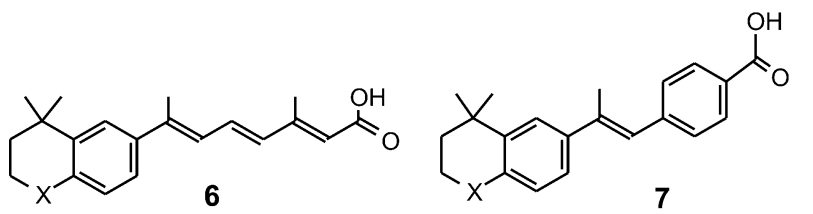<smiles>CC1(C)CCSc2ccc(NC(=O)c3ccc(C(=O)[PH3+])cc3)cc21</smiles><smiles>COC(=O)c1ccc(N(OC)C(=O)c2ccc3c(c2)C(C)(C)CCO3)cc1</smiles>

contain an aryl-fused heterocyclic ring as a modification, and several studies have shown that some heteroarotinoids demonstrate promising inhibition of various cancers as well as reduced toxicity. $2 c, 9,10$ Recent investigations of heteroarotinoids focused on structures containing a two-atom "linker" group (two atom moi ety connecting the two aryl rings), ${ }^{9}$ such as an amide (8), ${ }^{9 b}$ ester (9), ${ }^{9 \mathrm{c}}$ or $\mathrm{N}$-methoxyamide (10) ${ }^{9 \mathrm{~b}}$ functionality, among others. ${ }^{9 \mathrm{e}}$ It logically followed that synthesis and study of heteroarotinoids containing three-atom or even four-atom linkers, similar to those in the two-atom linker structures, would be worthwhile. Although a search of the literature reveal ed some retinoids with three or more-atom linkers, ${ }^{11-13}$ structures with only a few types of three-atom linker groups, such as chalcone (11), propenol (12), or $\alpha$-hydroxyamide groups (13), ${ }^{12}$ have been reported. Only one retinoid (14) containing a 1,4-diketone group as a four-atom linker was found. ${ }^{11 b}$<smiles>CC1(C)CCc2ccc(C(=O)/C=C/c3ccc(C(=O)O)cc3)cc2C1(C)C</smiles><smiles>COC(=O)c1ccc(C(=O)CCC(=O)c2ccc3c(c2)C(C)(C)CCC3(C)C)cc1</smiles>

The rationale for our present work is based upon the above citations and on the following observations. Utilizing a computer simulation program which, when modified slightly, al lowed the creation of flexible ligand/ receptor, or combinations thereof, it was discovered that the flexible ligands were at a slightly lower energy than
Table 1. Synthesis of Urea/Thiourea-Containing Heteroarotinoids $\mathbf{1 5 a}-\mathbf{h}$ from $\mathbf{1 8}$ or $\mathbf{2 4}$

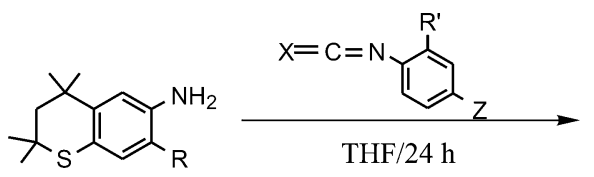

$$
\begin{aligned}
& 18(\mathrm{R}=\mathrm{H}) \\
& 24\left(\mathrm{R}=\mathrm{CH}_{3}\right)
\end{aligned}
$$<smiles>[Z]c1ccc(NC(=[X])Nc2cc3c(cc2[R])C(C)(C)CC(C)(C)C3)c([R])c1</smiles>

15a-h

\begin{tabular}{cllllcc}
\hline entry & $\mathrm{R}$ & $\mathrm{X}$ & $\mathrm{R}$ & \multicolumn{1}{c}{$\mathrm{Z}$} & product & yield (\%) \\
\hline 1 & $\mathrm{H}$ & $\mathrm{O}$ & $\mathrm{H}$ & $\mathrm{CO}_{2} \mathrm{Et}$ & $\mathbf{1 5 a}$ & 64 \\
2 & $\mathrm{H}$ & $\mathrm{S}$ & $\mathrm{H}$ & $\mathrm{CO}_{2} \mathrm{Et}$ & $\mathbf{1 5 b}$ & 92 \\
3 & $\mathrm{H}$ & $\mathrm{S}$ & $\mathrm{H}$ & $\mathrm{NO}_{2}$ & $\mathbf{1 5 c}$ & 83 \\
4 & $\mathrm{H}$ & $\mathrm{S}$ & $\mathrm{H}$ & $\mathrm{SO}_{2} \mathrm{NH}_{2}$ & $\mathbf{1 5 d}$ & 87 \\
5 & $\mathrm{H}$ & $\mathrm{S}$ & $\mathrm{CH}$ & $\mathrm{NO}_{2}$ & $\mathbf{1 5 e}$ & 82 \\
6 & $\mathrm{CH}_{3}$ & $\mathrm{O}$ & $\mathrm{H}$ & $\mathrm{CO}_{2} \mathrm{Et}$ & $\mathbf{1 5 f}$ & 43 \\
7 & $\mathrm{CH}_{3}$ & $\mathrm{~S}$ & $\mathrm{H}$ & $\mathrm{CO}_{2} \mathrm{Et}$ & $\mathbf{1 5 g}$ & 66 \\
8 & $\mathrm{CH}_{3}$ & $\mathrm{~S}$ & $\mathrm{H}$ & $\mathrm{SO}_{2} \mathrm{NH}_{2}$ & $\mathbf{1 5 h}$ & 56 \\
\hline
\end{tabular}

the fixed ligands based upon X-ray diffraction studies of RAR $\gamma \angle \mathrm{t}-\mathrm{RA}$ where both ligand and receptor were in rigid forms. ${ }^{9 c}$ Moreover, a urea or thiourea linker between the aryl rings introduces marked flexibility in the ligand and provides $\mathrm{H}$-bonding capablility in a strategic location within the molecule. Certain studies had suggested ${ }^{12,13}$ that the presence of a three-atom linker may increase specificity for the RARs. Others demonstrated that a linker with an attached, nonbulky functionality capable of hydrogen bonding via proton donation (such as via an $\mathrm{OH}$ ) enhanced RAR $\gamma$ selectivity. ${ }^{12,14}$ By constructing an agent possessing a semiflexible, three-atom linker with self-capability of hydrogen bonding through proton donation, it was reasoned that possibly a higher RAR $\gamma$ specificity would be produced, thus further increasing the efficacy of such retinoids. Furthermore, due to a high expression of RAR $\gamma$ in both skin ${ }^{15}$ and urogenital tissues, ${ }^{16}$ such an agent could be useful for the specific treatment of disorders such as melanoma or vulvarian carcinomas.

We now report the synthesis and biological activity of sulfur-containing heteroarotinoids $\mathbf{1 5 a}-\mathbf{1 5 h}$ with thiourea and urea linkers between the aryl rings. No heteroarotinoids with this type of linker have been reported. ${ }^{11 a}$ I nterestingly, the heteroarotinoids described did not activate retinoid receptors in two assays. However, the sulfur-containing heteroarotinoid systems 15a-h (Tables 1 and 2) demonstrated marked inhibitory ability for growth of ovarian cancer cell lines Caov3, OVCAR-3, SK-OV-3, ICU-101, and 222. The EC 50 values of the compounds were compared to that of 4-hydroxyphenyl retinamide (4-HPR), a clinically used retinoid, ${ }^{17}$ which has been shown to induce reactive oxygen species (ROS). Growth inhibition by heteroarotinoids 15a was associated with cell loss and induction of ROS.

\section{Results and Discussion}

Chemistry. Due to the reduced toxicity and cancer inhibition exhibited by some reported sulfur heteroarotinoids, $2 c, 9 a, 9 e$ a heterocyclic ring containing a gem-dimethyl group adjacent to a sulfur atom was chosen as part of 
Table 2. Potencies and Efficacies of Growth Inhibition of Ovarian Cancer Cell Lines by Heteroarotinoids 15a-h

\begin{tabular}{|c|c|c|c|c|c|c|}
\hline \multirow[b]{2}{*}{ product } & \multicolumn{2}{|c|}{ Caov-3 } & \multicolumn{2}{|c|}{ OVCAR-3 } & \multicolumn{2}{|c|}{ SK-OV-3 } \\
\hline & potency $^{\mathrm{a}}(\mu \mathrm{M})$ & efficacy $^{b}(\%)$ & potency $^{\mathrm{a}}(\mu \mathrm{M})$ & efficacy $^{b}(\%)$ & potency $^{\mathrm{a}}(\mu \mathrm{M})$ & efficacy ${ }^{b}(\%)$ \\
\hline 15a & $7.0 \pm 0.3$ & $63.7 \pm 5.1$ & $3.9 \pm 0.2$ & $160.4 \pm 3.0$ & $4.1 \pm 0.8$ & $71.8 \pm 6.4$ \\
\hline $15 b$ & $4.6 \pm 1.7$ & $38.1 \pm 5.4$ & $3.9 \pm 0.3$ & $133.8 \pm 5.4$ & $3.9 \pm 1.0$ & $64.9 \pm 6.9$ \\
\hline $15 c$ & $3.7 \pm 0.3$ & $89.2 \pm 4.3$ & $1.0 \pm 0.1$ & $155.2 \pm 2.2$ & $0.2 \pm 0.5$ & $69.1 \pm 2.4$ \\
\hline 15d & $7.0 \pm 3.5$ & $16.7 \pm 4.0$ & $4.4 \pm 0.8$ & $74.1 \pm 6.7$ & $7.8 \pm 0.8$ & $50.5 \pm 8.4$ \\
\hline $15 e$ & $7.4 \pm 0.7$ & $52.1 \pm 7.4$ & $3.7 \pm 0.2$ & $149.5 \pm 3.2$ & $3.9 \pm 1.2$ & $78.4 \pm 7.2$ \\
\hline $15 f$ & $10.2 \pm 0.7$ & $54.9 \pm 7.4$ & $4.7 \pm 1.0$ & $107.0 \pm 7.0$ & $7.2 \pm 2.3$ & $75.7 \pm 16.4$ \\
\hline $15 \mathrm{~g}$ & $4.0 \pm 2.8$ & $37.4 \pm 7.8$ & $4.4 \pm 0.4$ & $114.4 \pm 4.9$ & $4.4 \pm 2.3$ & $85.4 \pm 9.5$ \\
\hline $15 \widehat{h}$ & $0.9 \pm 0.7$ & $30.3 \pm 7.4$ & $4.4 \pm 0.6$ & $90.0 \pm 6.2$ & $6.9 \pm 1.5$ & $67.7 \pm 13.7$ \\
\hline 25 (4-HPR) & $3.7 \pm 0.2$ & $100.0 \pm 3.7$ & $6.9 \pm 0.3$ & $100.0 \pm 4.7$ & $8.2 \pm 0.6$ & $100.0 \pm 3.9$ \\
\hline
\end{tabular}

a The potency difference is the concentration that exerts half-maximal activity ( $\mathrm{EC}_{50}$ value) derived from a graph of percent growth inhibition versus concentration using GraphPad Software. ${ }^{b}$ The efficacy is the growth inhibition activity of the compound at $10 \mu \mathrm{M}$ concentration relative to the maximum activity observed for 4-HPR with the respective cell line. The maximal growth inhibition activity of $10 \mu \mathrm{M}$ 4-HPR (25) was $61.97 \%$ for Caov-3, $43.1 \%$ for OVCAR-3, and $64.9 \%$ for SK-OV-3. The results represent the average and standard error of three experiments performed in triplicate.

\section{Scheme 1}

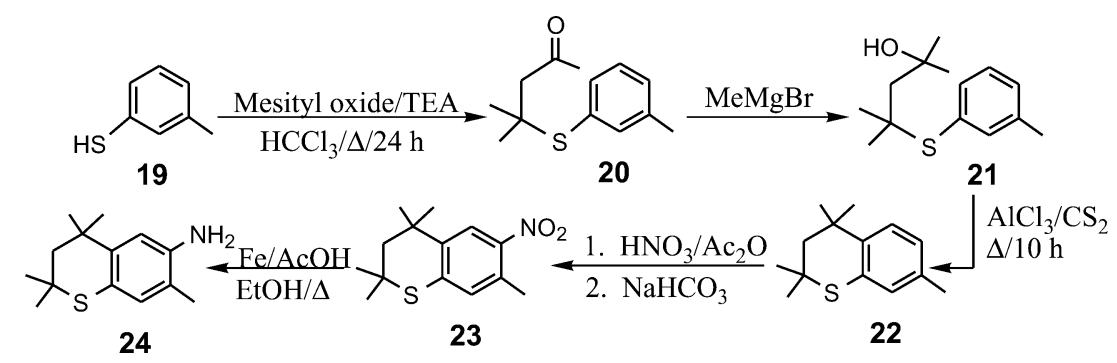

the structural foundation for this series of compounds. It was conceived that the conversion $\mathbf{1 6} \rightarrow \mathbf{1 7} \rightarrow \mathbf{1 8}$

$$
\text { (16 }
$$

would provide key intermediate amine $\mathbf{1 8}$, which could be utilized to incorporate the desired structural characteristics into the target heteroarotinoids $\mathbf{1 5 a}-\mathbf{e}$. Although amine $\mathbf{1 8}$ is known, ${ }^{9 b}$ different conditions were employed here as outlined above. The reaction sequence began with the nitration of the thiochroman $16^{10 a}$ using $\mathrm{HNO}_{3} / \mathrm{Ac}_{2} \mathrm{O}^{18}$ to afford the 6-isomer $\mathbf{1 7}$ in a modest yield (26\%) with many other products being formed. However, in this case only 1 equiv of the nitrating agent was used, as compared to 2 equiv in the reported procedure, ${ }^{9 \mathrm{~b}}$ and with little loss in yield ( $27 \%$ being reported previously ${ }^{9 b}$ ). Reduction of the nitro group in $\mathbf{1 7}$ was accomplished using iron/acetic acid ${ }^{19}$ in refluxing EtOH to yield amine $18(40 \%)$. Although a previous method ${ }^{9 b}$ recorded a yield of $50 \%$ for amine $\mathbf{1 8}$ from the reduction of the nitro group in 17, it required the use of a very large excess of expensive $\mathrm{TiCl}_{3} / \mathrm{HCl}$. In addition, the reaction workup was complicated and required the handling of titanium salts. In contrast, the iron/acetic acid approach is lowcost and the workup is relatively simple.

It seemed reasonable to prepare analogues of $\mathbf{1 5 a}$, $\mathbf{1 5 b}$, and $\mathbf{1 5 d}$ possessing a methyl group attached to the fused ring system at the $\mathrm{C} 7$ position, a situation which could assist in determining more precisely the ligandreceptor interactions within the hydrophobic region of the receptor's ligand-binding pocket (LBP). $.9 \mathrm{~b}, c, 20$
Heteroarotinoid anal ogues $\mathbf{1 5 f}-\mathbf{h}$ were envisioned to be accessible from unknown amine $\mathbf{2 4}$. Thus, the conversions of $\mathbf{1 9} \rightarrow \mathbf{2 0} \rightarrow \mathbf{2 1} \rightarrow \mathbf{2 2} \rightarrow \mathbf{2 3} \rightarrow \mathbf{2 4}$ (Scheme 1) was implemented and provided $\mathbf{2 4}$, which was then used to generate the targets $\mathbf{1 5 a}-\mathbf{h}$ (Table 1 ). The sequence utilized 3-methylthiophenol in a Michael addition to mesityl oxide and yielded ketone 20 (87\%). Treatment of ketone $\mathbf{2 0}$ with excess $\mathrm{MeMgBr}$ gave alcohol $\mathbf{2 1}$ (84\%). Dehydration-cyclization of $\mathbf{2 1}$ was then accomplished by the action of $\mathrm{AlCl}_{3}$ in $\mathrm{CS}_{2}$ to afford thiochroman 22 (93\%). Nitration of thiochroman 22 was achieved using $\mathrm{HNO}_{3} / \mathrm{Ac}_{2} \mathrm{O}^{18}$ to afford the 6-isomer 23 in a modest yield (26\%), with several byproducts being formed, including some via oxidation of the sulfur atom. Reduction of the nitro group in $\mathbf{2 3}$ occurred with Fe/ $\mathrm{AcOH}^{18}$ in refluxing EtOH to yield amine 24 (45\%).

The thi ourea or urea group (Table 1) was chosen as a three-atom linker due to its somewhat flexible nature, which might allow a good fit into the RARs and therefore enhance activation. Moreover, a thiourea or urea function provides two $-\mathrm{NH}$ - groups capable of hydrogen bonding with the receptor, thus possibly improving RAR $\gamma$ selectivity. To generate the desired heteroarotinoids $\mathbf{1 5 a}-\mathbf{h}$ possessing urea linking groups, the conversions of $\mathbf{1 8} \rightarrow \mathbf{1 5 a}-\mathbf{e}$ and $\mathbf{2 4} \rightarrow \mathbf{1 5 f}-\mathbf{h}$ (Table 1) were performed. Amine $\mathbf{1 8}$ (or $\mathbf{2 4}$ ) was coupled with isocyanates and/or isothiocyanates in dry THF. The crude products were recrystallized from appropriate solvent systems to afford the desired compound with generally good yields.

\section{Biological Activity}

Cisplatin is used as the current standard of care chemotherapy administered to patients with ovarian cancer. Compounds 15a-h (Table 2) were evaluated for their ability to inhibit the growth of three ovarian carcinoma cell lines, Caov-3, OVCAR-4-, and SK-OV-3, 


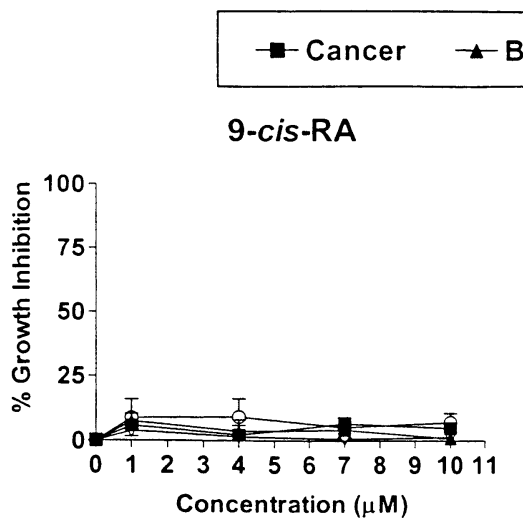

$15 b$

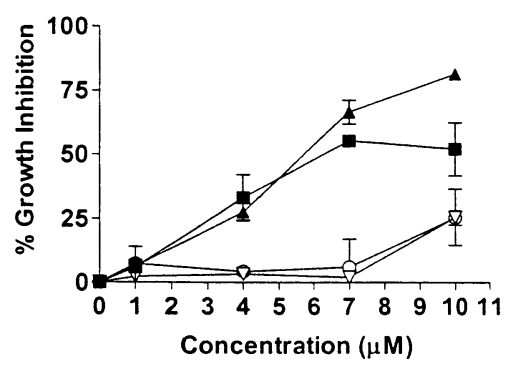

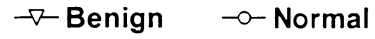

$15 a$

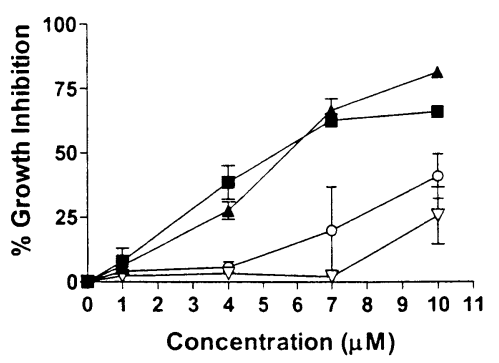

$15 c$

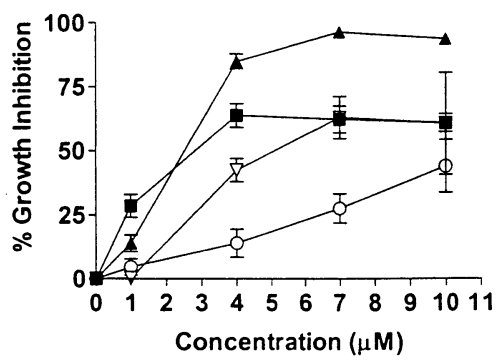

4-HPR

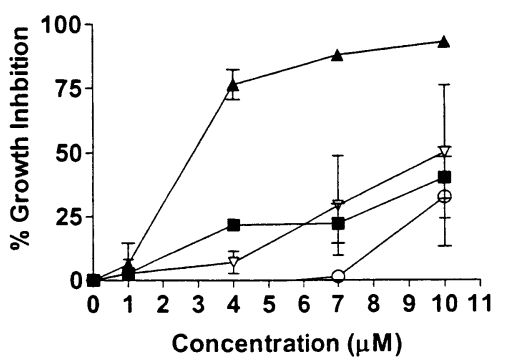

Figure 1. Heteroarotinoids and 4-HPR exhibit greater activity against cancerous and borderline ovarian cells than against benign ovarian cells and normal endometrial cells. Cultures of an ovarian cancer cell line (OVCAR-3), a borderline ovarian tumor (O1), a benign ovarian cyst (O3), and normal endometrial cells weretreated with a range of concentrations of the indicated retinoids or the same vol ume of solvent as a control. The percentage of growth inhibition after 3 days of treatment was determined using the MTS assay. The results represent the average and standard deviation of three experiments performed in triplicate.

which vary in their sensitivities to retinoids and cisplatin. The OVCAR-3 is cisplatin resistant, while Caov-3 and SK-OV-3 are cisplatin-sensitive. The SK-OV-3 line is resistant to classical retinoid receptor-active retinoids, while Caov-3 and OVCAR-3 are sensitive to these retinoids. The activities of the heteroarotinoids were compared to that of the well-known retinoid 4-HPR (25), ${ }^{17}$ which has demonstrated chemoprevention activ-<smiles>CC1=C(/C=C/C(C)=C/C=C/C(C)=C/C(=O)Nc2ccc(O)cc2)C(C)(C)CCC1</smiles>

25 (4-HPR)

ity against ovarian cancer in clinical trials. The potencies and efficacies derived from the growth inhibition curves are summarized in Table 2.

All three cell lines were growth inhibited by all of the heteroarotinoids tested, with $\mathrm{EC}_{50}$ values in the micromolar range, similar to 4-HPR (25). I nterestingly, the cisplatin-resistant OVCAR-3 cell line and retinoic acid- resistant SK-OV-3 cell line were sensitive to these compounds. The individual substitutions induced slight alterations in the efficacy in a cell-dependent manner. Overall, compound $\mathbf{1 5 c}$, containing an $\mathrm{NO}_{2}$ group, exhibited the highest activities against all cell lines tested in terms of strong efficacies and very good potencies. Regarding potencies, $\mathbf{1 5 c}$ was actually as good or more potent than the clinical agent 4-HPR (25).

Given the potential dinical application of these compounds for prevention and treatment of ovarian cancer, it was important to determine if the agents were toxic to normal cells and to pre-neoplastic lesions that had not yet become cancerous. To evaluate the therapeutic ratios, the growth inhibition activities of heteroarotinoids $\mathbf{1 5 a}-\mathbf{c}$, 9-cis-retinoic acid (9-c-RA, 2), and 4-HPR (25) in primary cultures derived from normal endometrial cells were compared to the activities in cultures of the OVCAR-3 ovarian cancer cell line, a borderline ovarian tumor (O1), and a benign ovarian tumor (O3) (Figure 1). The 9-cis-retinoic acid (9-c-RA, 2) did not inhibit growth of any of these cultures. Heteroarotinoids 15a-c and 4-HPR (25) exhibited 

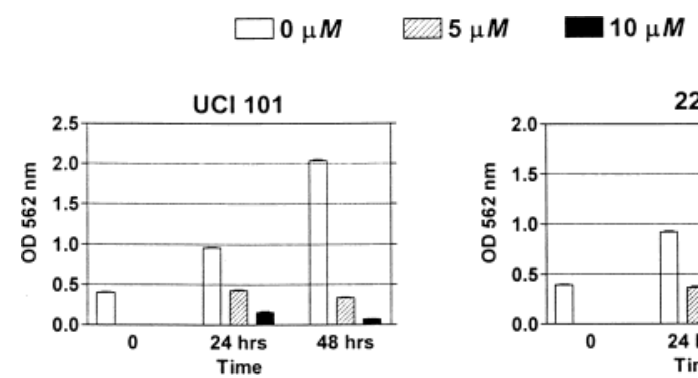

Figure 2. Growth inhibition of ovarian cancer cell lines is due to cell loss within $48 \mathrm{~h}$. The optical density (OD) represents the number of cells present at the indicated times of treatment with $\mathbf{1 5 c}$.

strong growth inhibition against the ovarian cancer cell line and weak inhibition of the normal endometrial cells, demonstrating good therapeutic ratios. The heteroarotinoids exhibited strong growth inhibition against the borderline tumor, demonstrating potential to prevent progression of preneoplastic lesions to cancer, while 4-HPR (25) exhibited weak activity against the borderline culture. Although benign ovarian cysts rarely progress to cancer, they are often removed surgically due to the deleterious effects of an increasing size. Heteroarotinoid 15c exhibited the most potent growth inhibition activity $(4 \mu \mathrm{M})$ against the benign ovarian culture.

The strong growth inhibition activity of the heteroarotinoids suggests that cell loss may be due to induction of apoptosis. In two related studies ${ }^{9 a, 21}$ with $15 \mathbf{a}-\mathbf{c}$ (previously labeled SHetA4, SHetA3, and SHetA2, respectively), ${ }^{9 a, 21}$ it was demonstrated that these agents induced apoptosis in ovarian and head/neck cancer cell lines. To further evaluate the mechanism of growth inhibition in ovarian cancer, the effects of $\mathbf{1 5 c}$ at two different concentrations ( 5 and $10 \mu \mathrm{M}$ ) were evaluated on two additional ovarian cell lines ( $\mathrm{UCl} 101$ and 222). Within $24 \mathrm{~h}$ of treatment, the growth of both cell lines were completely blocked by $\mathbf{1 5 c}$ at both concentrations (Figure 2). Within $48 \mathrm{~h}$, cell loss was apparent at the $10 \mu \mathrm{M}$ concentration (Figure 2). To further investigate the mechanism of this cell loss, ROS was measured in both cell lines after treatment with $\mathbf{1 5 c}$ over a range of concentrations for $24 \mathrm{~h}$. At $1 \mu \mathrm{M}$ concentration, 15c did not induce ROS, while at 5 and $10 \mu \mathrm{M}$ concentrations of 15c (SHetA2), ROS was induced in a dose-response manner (Figure 3).

\section{Conclusions}

Chemoprevention activity by 4-HPR (25) is thought to induce apoptosis through retinoic acid-receptor-

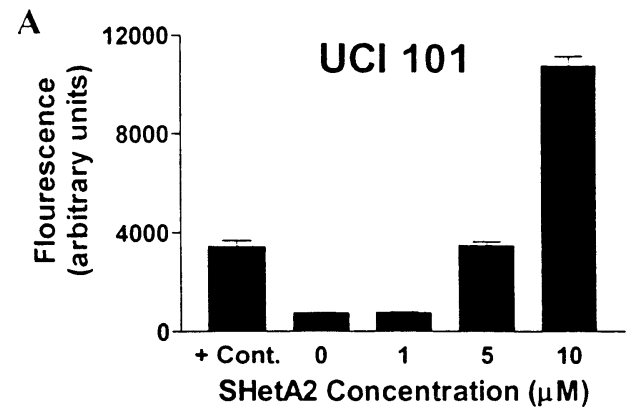

independent mechanisms only at concentrations above those achieved in clinical chemoprevention trials. ${ }^{22}$ At concentrations $<1 \mu \mathrm{M}$, however, 25 appears to behave similarly to classical retinoids by inducing differentiation through a receptor-dependent mechanism. ${ }^{17,22}$ Since $\mathbf{1 5} \mathbf{a}-\mathbf{h}$ did not exhibit RAR $\gamma$ receptor activation in the assays employed, it is conceivable that these heteroarotinoids may act by way of a different receptor or by an independent pathway. ${ }^{17,22}$

The efficacy of these heteroarotinoi ds against ovarian cancer cell lines which are resistant to standard cisplatin chemotherapy and to trans-retinoic acid (1) suggests that these agents may possess a unique mode of action. This is consistent with the lack of direct activation of the retinoic acid receptors. The present study demonstrates that the growth inhibition by $\mathbf{1 5 a}-\mathbf{c}$ is due to cell loss. In a related study, ${ }^{\text {aa }}$ it was shown that cell loss in the OVCAR-3 ovarian cancer cell line was due to induction of apoptosis. Since $\mathbf{1 5 c}$ exhibited the highest degree of growth inhibition in a variety of cell lines, this compound was evaluated in more detail for the mechanism of apoptosis. In a study of head and neck cancer cell lines, specific inhibitors were used to demonstrate that the induction of apoptosis by $\mathbf{1 5 c}$ was mediated through induction of ROS, G2 cell cycle arrest, alterations in mitochondrial membrane permeability transition (MPT), release of cytochrome $c$ from the mitochondria to the cytosol, and activation of caspase $3 .{ }^{21}$ In addition, a specific antagonist of retinoic acid receptors was utilized to confirm that $\mathbf{1 5 c}$ induced apoptosis independent of the retinoic acid receptors. ${ }^{21}$ The current study clearly demonstrates that ovarian cancer cell lines also generate ROS in response to treatment with heteroarotinoid $\mathbf{1 5 c}$.

The differential effects of $\mathbf{1 5 a}-\mathbf{c}$ on normal versus cancer cells observed in this study clearly show that such agents with urea and/or thiourea linkers have a favorable therapeutic ratio in that cancer and precancer cells were growth inhibited to much greater extents than normal or benign cells. This favorable therapeutic ratio was also observed in another study that illustrated that $\mathbf{1 5 b}$ and $\mathbf{1 5 c}$ inhibited the growth of OVCAR-3 xenograph tumors in an animal model to similar degrees as noted with 4-HPR (25) without any evidence of toxicity. ${ }^{23}$ The lack of hypervitaminosis A toxicities of $\mathbf{1 5 b}$ and $\mathbf{1 5 c}$ in the animal model supports our observations that these compounds act independently of the retinoic acid receptors. ${ }^{\text {9a, } 23,24}$

In summary, we have developed procedures to obtain a variety of heteroarotinoids with a urea or thiourea linking group. The series of heteroarotinoids $\mathbf{1 5 a}-\mathbf{h}$

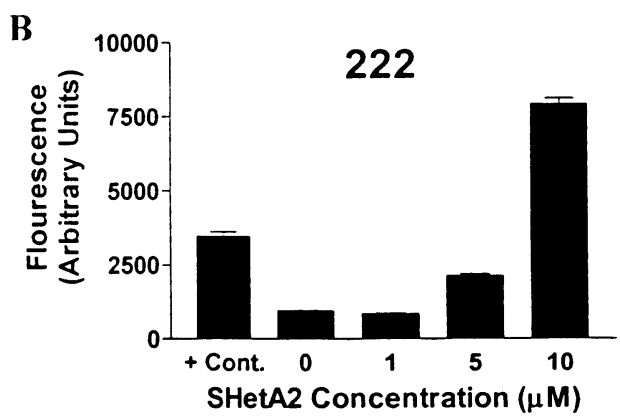

Figure 3. Generation of ROS in ovarian cancer cell lines. After $24 \mathrm{~h}$ of treatment with the indicated amount of $\mathbf{1 5 c}$, the UCl 101 cell line (A) and the 222 cell line (B) were evaluated for ROS as indicated by fluoresence units. 
contain the first such examples possessing flexible urea or thiourea groups as three-atom linkers. ${ }^{11}$ The syntheses involved a coupling reaction of various isocyanates or isothiocyanates in THF with previously rare or unknown amines $\mathbf{1 8}$ and $\mathbf{2 4}$, respectively. The heteroarotinoids described herein effectively inhibit growth of a variety of ovarian cancer cell lines. Some of the agents have demonstrated anticancer activities and a therapeutic window comparable to that of the clinical agent 4-HPR (25). Thesensitivity of cisplatin-resistant OVCAR-3 cell lines suggests the potential use of these heteroarotinoids in preventing recurrence of ovarian cancer in patients who have received cisplatin chemotherapy. Other bi ol ogical effects of $\mathbf{1 5 a}$-chaveappear ed el sewhere. ${ }^{9 a}$ Moreover, $\mathbf{1 5} \mathbf{a}$ and $\mathbf{1 5} \mathbf{b}$ act as antagonists of Mycobacterium bovis BCG, which suggests the agents inhibit mycolic acid synthesis (see the companion paper). ${ }^{25}$

Results from the present work and related studies $^{9,21,23}$ demonstrate that this new class of heteroarotinoids induces apoptosis in cancer cells to a greater extent than in normal cells through a mechanism that is independent of retinoic acid receptor activation and involves the generation of ROS. ${ }^{26}$ Compound 15c (labeled ShetA2 in the literature ${ }^{9 a}$ ) is now in predinical development for cancer prevention and treatment through the National Cancer Institutes ( $\mathrm{NCl}$ ) Rapid Access to Intervention Development (RAID) program. Thus, the present work provides a background for additional exploration of the structures of heteroarotinoids as anticancer agents.

\section{Experimental Section}

Commercial reagents and solvents were used as received unless otherwise noted. Anhydrous THF was obtained by distillation from a purple solution of sodium and benzophenone. All of the isocyanates and isothiocyanates were commercially available and were obtained from Lancaster Synthesis, Inc., Windham, NH. Unless otherwise indicated, all reactions were run under dry $\mathrm{N}_{2}$ and all purification beyond recrystallization was done via flash chromatography, utilizing J. T. Baker flash chromatography silica gel packing, $40 \mu \mathrm{m}$ particle size. Melting points were determined using a ThomasHoover melting point apparatus and were uncorrected. IR spectra were obtained using a Perkin-Elmer 2000 FT-IR spectrometer as films or $\mathrm{KBr}$ pellets. Unless stated otherwise, all ${ }^{1} \mathrm{H}$ and ${ }^{13} \mathrm{C}$ NMR spectra were performed using $\mathrm{DCCl}_{3}$ as the solvent and obtained using a Varian UNITYINOVA 400 BB NMR spectrometer operating at 399.99 and $100.01 \mathrm{MHz}$, respectively. Signals were referenced to TMS. Elemental analyses were performed by Atlantic Microlab, I nc., N orcross, GA.

Although the intermediates and final products appeared to be relatively stable in light, precautions were taken to minimize exposure to any light source and to the atmosphere. In the purified state, all products were stored in the cold and dark without significant decomposition. Intermediates appeared to be similar in sensitivity and were treated likewise.

General Procedure for the Preparation of Heteroarotinoids $\mathbf{1 5 a}-\mathbf{h}$ from Amine 18 or 24 . To a solution of amine 18 or $24(1.0 \mathrm{mmol})$ in dry THF $(4.5 \mathrm{~mL})$ at $0{ }^{\circ} \mathrm{C}$ was added dropwise the desired isocyanate or isothiocyanate (1.02 $\mathrm{mmol})$ in dry THF (5 mL) over $3 \mathrm{~min}$. After the addition, the reaction mixture was allowed to warm to room temperature and then was stirred for $24 \mathrm{~h}$. The solvent was evaporated, and the residue was recrystallized to give an analytically pure sample of the corresponding heteroarotinoid.

Ethyl 4- $[$ [N-(2,2,4,4-Tetramethylthiochroman-6-yl)carbamoyl]amino\} benzoate (15a). The ester was prepared from $18(1.0 \mathrm{mmol})$ and 4-ethoxycarbonyl phenyl isocyanate
(195 mg, $1.02 \mathrm{mmol}$ ). Recrystallization $\left(\mathrm{H}_{2} \mathrm{CCl}_{2}\right.$ :pentane) gave 15a (263 mg, 64\%) as a white solid: $\mathrm{mp} 200-201{ }^{\circ} \mathrm{C}$; I R (KBr) 3342, 3190, 1720, $1652 \mathrm{~cm}^{-1} ;{ }^{1} \mathrm{H}$ NMR $\delta 1.32(\mathrm{~s}, 6 \mathrm{H}), 1.35(\mathrm{t}$, $\mathrm{J}=6.87 \mathrm{~Hz}, 3 \mathrm{H}), 1.38(\mathrm{~s}, 6 \mathrm{H}), 1.89(\mathrm{~s}, 2 \mathrm{H}), 4.31(\mathrm{q}, \mathrm{J}=7.0$ $\mathrm{Hz}, 2 \mathrm{H}), 6.91(\mathrm{dd}, \mathrm{J}=11.20,2.80 \mathrm{~Hz}, 1 \mathrm{H}), 7.04(\mathrm{~d}, \mathrm{~J}=8.38$ $\mathrm{Hz}, 1 \mathrm{H}), 7.26$ (bs, $1 \mathrm{H}), 7.35(\mathrm{~d}, \mathrm{~J}=8.65 \mathrm{~Hz}, 2 \mathrm{H}), 7.42(\mathrm{~d}, \mathrm{~J}$ $=2.80 \mathrm{~Hz}, 1 \mathrm{H}), 7.51(\mathrm{bs}, 1 \mathrm{H}), 7.91(\mathrm{~d}, \mathrm{~J}=11.60 \mathrm{~Hz}, 2 \mathrm{H}) ;{ }^{13} \mathrm{C}$ NMR ppm 14.20, 31.75, 32.13, 35.84, 42.03, 54.07, 61.87, $118.42,120.02,120.92,124.78,128.93,129.02,130.92,134.28$, 142.33, 144.09, 153.76, 166.86. Anal. $\left(\mathrm{C}_{23} \mathrm{H}_{28} \mathrm{~N}_{2} \mathrm{O}_{3} \mathrm{~S}\right) \mathrm{C}, \mathrm{H}, \mathrm{N}$, S.

Ethyl 4-\{[N-(2,2,4,4-Tetramethylthiochroman-6-yl)thiocarbamoyl]amino benzoate (15b). The ester was prepared from $18(1.0 \mathrm{mmol})$ and 4-ethoxycarbonyl phenyl isothiocyanate $(211 \mathrm{mg}, 1.02 \mathrm{mmol})$. Recrystallization $\left(\mathrm{H}_{2} \mathrm{CCl}_{2}\right.$ : pentane) gave 15b (394 mg, 92\%) as a white solid: $\mathrm{mp}$ 134$135{ }^{\circ} \mathrm{C}$; IR (KBr) 3285, 3138, $1688 \mathrm{~cm}^{-1}$; ${ }^{1} \mathrm{H}$ NMR $\delta 1.35(\mathrm{~m}, 9$ $\mathrm{H}), 1.43(\mathrm{~s}, 6 \mathrm{H}), 1.95(\mathrm{~s}, 2 \mathrm{H}), 4.32(\mathrm{q}, \mathrm{J}=7.14 \mathrm{~Hz}, 2 \mathrm{H}), 7.03$ $(\mathrm{dd}, \mathrm{J}=6.18,2.20 \mathrm{~Hz}, 1 \mathrm{H}), 7.15(\mathrm{~d}, \mathrm{~J}=8.24 \mathrm{~Hz}, 1 \mathrm{H}), 7.37$ $(d, J=2.06 \mathrm{~Hz}, 1 \mathrm{H}), 7.53(\mathrm{~d}, \mathrm{~J}=8.65 \mathrm{~Hz}, 2 \mathrm{H}), 8.01(\mathrm{bs}, 1 \mathrm{H})$, $8.02(\mathrm{~d}, \mathrm{~J}=6.87 \mathrm{~Hz}, 2 \mathrm{H}), 8.35(\mathrm{bs}, 1 \mathrm{H}) ;{ }^{13} \mathrm{C}$ NMR ppm 14.16, $31.46,32.35,35.66,42.25,53.72,60.97,122.95,123.65,124.04$, $127.72,129.26,130.65,132.97,133.07,141.86,144.70,165.96$, 179.21. Anal. $\left(\mathrm{C}_{23} \mathrm{H}_{28} \mathrm{~N}_{2} \mathrm{O}_{2} \mathrm{~S}_{2}\right) \mathrm{C}, \mathrm{H}, \mathrm{N}, \mathrm{S}$.

[(4-Nitrophenyl)amino][(2,2,4,4-tetramethylthiochroman-6-yl)amino]methane-1-thione (15c). The compound was prepared from $18(1.0 \mathrm{mmol})$ and 4-nitrophenyl isothiocyanate (184 mg, $1.02 \mathrm{mmol})$. Recrystallization $\left(\mathrm{HCCl}_{3}\right.$ :pentane) gave $15 \mathrm{c}$ (333 $\mathrm{mg}, 83 \%$ ) as a bright yellow solid: $\mathrm{mp}$ 153-155 ${ }^{\circ} \mathrm{C}$; IR (KBr) 3219, $3189 \mathrm{~cm}^{-1}$; ${ }^{1} \mathrm{H}$ NMR (DMSO-d $\mathrm{d}_{6}$ ) $\delta 1.39(\mathrm{~s}, 6 \mathrm{H}), 1.44(\mathrm{~s}, 6 \mathrm{H}), 1.97(\mathrm{~s}, 2 \mathrm{H}), 7.03(\mathrm{dd}, \mathrm{J}=6.04$, $2.20 \mathrm{~Hz}, 1 \mathrm{H}), 7.19(\mathrm{~d}, \mathrm{~J}=8.24 \mathrm{~Hz}, 1 \mathrm{H}), 7.33(\mathrm{~d}, \mathrm{~J}=2.20 \mathrm{~Hz}$, $1 \mathrm{H}), 7.73(\mathrm{~d}, \mathrm{~J}=9.06 \mathrm{~Hz}, 2 \mathrm{H}), 7.95(\mathrm{bs}, 1 \mathrm{H}), 8.18(\mathrm{~d}, \mathrm{~J}=7.0$ $\mathrm{Hz}, 2 \mathrm{H}$ ), 8.44 (bs, $1 \mathrm{H}$ ); ${ }^{13} \mathrm{C}$ NMR (DMSO-d 6 ) ppm 31.47, 32.83, $35.71,42.35,53.58,122.98,123.03,124.18,124.62,129.58$, $132.28,133.94,143.97,144.56,145.18,179.01$. Anal. $\left(\mathrm{C}_{20} \mathrm{H}_{23} \mathrm{~N}_{3} \mathrm{O}_{2} \mathrm{~S}_{2}\right)$ $\mathrm{C}, \mathrm{H}, \mathrm{N}, \mathrm{S}$.

4-(\{[(2,2,4,4-Tetramethyl(3H-benzo[3,4-e]thian-6-yl))amino]thioxomethyl \}amino)benzenesulfonamide (15d). The sulfamide was prepared from $\mathbf{1 8}(1.0 \mathrm{mmol})$ and 4-isothiocyanatobenzenesulfonamide $(218 \mathrm{mg}, 1.02 \mathrm{mmol})$. Recrystallization (95\% EtOH) gave $\mathbf{1 5 d}(378 \mathrm{mg}, 87 \%)$ as a white solid: $\mathrm{mp} 191-193{ }^{\circ} \mathrm{C}$; IR (KBr) 3358, 3272, 1340, $1167 \mathrm{~cm}^{-1} ;{ }^{1} \mathrm{H}$ NMR $\delta 1.32(\mathrm{~s}, 6 \mathrm{H}), 1.37(\mathrm{~s}, 6 \mathrm{H}), 1.91(\mathrm{~s}, 2 \mathrm{H}), 7.00(\mathrm{~d}, \mathrm{~J}=$ $6.12 \mathrm{~Hz}, 1 \mathrm{H}$ ), 7.21 (dd, J = 8.67, $1.98 \mathrm{~Hz}, 1 \mathrm{H}), 7.29$ (bs, $2 \mathrm{H}$ ), $7.58(\mathrm{~d}, \mathrm{~J}=2.03 \mathrm{~Hz}, 1 \mathrm{H}), 7.65(\mathrm{~d}, \mathrm{~J}=7.67 \mathrm{~Hz}, 2 \mathrm{H}), 7.73(\mathrm{~d}$, $\mathrm{J}=7.64 \mathrm{~Hz}, 2 \mathrm{H}$ ), 10.97 (bs, $1 \mathrm{H}), 10.02\left(\mathrm{bs}, 1 \mathrm{H}\right.$ ); ${ }^{13} \mathrm{C} \mathrm{NMR}$ ppm 31.24, 32.25, 35.27, 42.00, 53.43, 122.02, 122.69, 126.33, $127.49,128.14,136.44,139.16,142.60,142.86,179.48$. Anal. $\left(\mathrm{C}_{20} \mathrm{H}_{25} \mathrm{~N}_{3} \mathrm{O}_{2} \mathrm{~S}_{3}\right) \mathrm{C}, \mathrm{H}, \mathrm{N}, \mathrm{S}$.

[(2-Methyl-4-nitrophenyl)amino][(2,2,4,4-tetramethylthiochroman-6-yl)amino]methane-1-thione (15e). The compound was prepared from $18(1.0 \mathrm{mmol})$ and 2-methyl-4nitrophenyl isothiocyanate (198 mg, $1.02 \mathrm{mmol})$. Recrystallization ( $\mathrm{HCCl}_{3}$ :hexanes) gave $\mathbf{1 5 e}(340 \mathrm{mg}, 82 \%)$ as a white

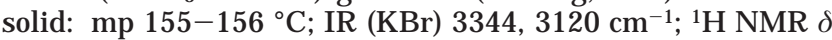
$1.39(\mathrm{~s}, 6 \mathrm{H}), 1.43(\mathrm{~s}, 6 \mathrm{H}), 1.97(\mathrm{~s}, 2 \mathrm{H}), 2.25(\mathrm{~s}, 3 \mathrm{H}), 7.05$ (dd, $\mathrm{J}=6.04,2.20 \mathrm{~Hz}, 1 \mathrm{H}), 7.21(\mathrm{~d}, \mathrm{~J}=8.24 \mathrm{~Hz}, 1 \mathrm{H}), 7.37(\mathrm{~d}, \mathrm{~J}$ $=2.06 \mathrm{~Hz}, 1 \mathrm{H}), 7.47(\mathrm{bs}, 1 \mathrm{H}), 8.02(\mathrm{~m}, 4 \mathrm{H}) ;{ }^{13} \mathrm{C} \mathrm{NMR}$ ppm $17.91,31.47,32.37,35.77,42.40,53.367,122.10,123.74$, $124.80,125.87,126.44,129.69,132.32,133.54,134.41,142.45$, 145.31, 145.49, 179.74. Anal. $\left(\mathrm{C}_{21} \mathrm{H}_{25} \mathrm{~N}_{3} \mathrm{O}_{2} \mathrm{~S}_{2}\right) \mathrm{C}, \mathrm{H}, \mathrm{N}, \mathrm{S}$.

Ethyl 4- $\{[\mathrm{N}-(\mathbf{2}, \mathbf{2}, \mathbf{4}, \mathbf{4}, \mathbf{7}-\mathrm{Pentamethylthiochroman-6-yl)-}$ carbamoyl]amino\} benzoate (15f). The ester was prepared from $24(1.0 \mathrm{mmol})$ and 4-ethoxycarbonylphenyl isocyanate (195 mg, $1.02 \mathrm{mmol})$. Recrystal lization $\left(\mathrm{H}_{2} \mathrm{CCl}_{2}\right.$ :pentane) gave $15 f(183 \mathrm{mg}, 43 \%)$ as a white solid: $\mathrm{mp} 121-123^{\circ} \mathrm{C}$; IR ( $\left.\mathrm{KBr}\right)$ $3331,3203,1716,1659 \mathrm{~cm}^{-1}$; ${ }^{1 H}$ NMR $\delta 1.33(\mathrm{~s}, 6 \mathrm{H}), 1.35(\mathrm{t}$, $\mathrm{J}=6.72 \mathrm{~Hz}, 3 \mathrm{H}), 1.38(\mathrm{~s}, 6 \mathrm{H}), 1.89(\mathrm{~s}, 2 \mathrm{H}), 2.12(\mathrm{~s}, 3 \mathrm{H})$, $4.31(\mathrm{q}, \mathrm{J}=7.0 \mathrm{~Hz}, 2 \mathrm{H}), 6.86$ (bs, $1 \mathrm{H}), 6.95(\mathrm{~s}, 1 \mathrm{H}), 7.31$ (d, $\mathrm{J}=8.52 \mathrm{~Hz}, 2 \mathrm{H}), 7.49(\mathrm{~s}, 1 \mathrm{H}), 7.53(\mathrm{bs}, 1 \mathrm{H}), 7.88(\mathrm{~d}, \mathrm{~J}=8.79$ $\mathrm{Hz}, 2 \mathrm{H}) ;{ }^{13} \mathrm{C} N M R$ ppm 14.32, 17.16, 31.53, 32.58, 35.35, 42.16, 
$54.02,60.82,118.20,124.08,124.63,129.90,130.42,130.78$, $132.09,134.28,141.60,142.83,153.82,166.40$. Anal. $\left(\mathrm{C}_{24} \mathrm{H}_{30} \mathrm{~N}_{2} \mathrm{O}_{3} \mathrm{~S}\right)$ C, H, N, S.

Ethyl 4-\{[N-(2,2,4,4,7-Pentamethylthiochroman-6-yl)thiocarbamoyl]amino\} benzoate (15g). The ester was prepared from $24(1.0 \mathrm{mmol})$ and 4-ethoxycarbonyl phenyl isothiocyanate ( $211 \mathrm{mg}, 1.02 \mathrm{mmol}$ ). Recrystallization (ether:pentane) gave $\mathbf{1 5 g}$ (292 $\mathrm{mg}, 66 \%)$ as a white solid: $\mathrm{mp} 128-129{ }^{\circ} \mathrm{C}$; IR (KBr) 3210, 3117, $1730 \mathrm{~cm}^{-1}$; ${ }^{1} \mathrm{H}$ NMR $\delta 1.35(\mathrm{~m}, 9 \mathrm{H}), 1.43$ $(\mathrm{s}, 6 \mathrm{H}), 1.94(\mathrm{~s}, 2 \mathrm{H}), 2.24(\mathrm{~s}, 3 \mathrm{H}), 4.31(\mathrm{q}, \mathrm{J}=7.14 \mathrm{~Hz}, 2 \mathrm{H})$, $7.06(\mathrm{~s}, 1 \mathrm{H}), 7.33(\mathrm{~s}, 1 \mathrm{H}), 7.53(\mathrm{~d}, \mathrm{~J}=8.51 \mathrm{~Hz}, 2 \mathrm{H}), 8.70$ (bs, $1 \mathrm{H}), 7.99(\mathrm{~d}, \mathrm{~J}=8.52 \mathrm{~Hz}, 2 \mathrm{H}), 8.13(\mathrm{bs}, 1 \mathrm{H}) ;{ }^{13} \mathrm{C} \mathrm{NMR} \mathrm{ppm}$ $14.25,17.19,31.53,32.63,35.36,42.32,53.71,60.94,123.20$, $126.02,127.60,130.39,131.21,132.98,134.03,141.92,142.06$, 144.70, 165.79, 179.65. Anal. $\left(\mathrm{C}_{24} \mathrm{H}_{30} \mathrm{~N}_{2} \mathrm{O}_{2} \mathrm{~S}_{2}\right) \mathrm{C}, \mathrm{H}, \mathrm{N}, \mathrm{S}$

4-(\{[(2,2,4,4,7-Pentamethyl(3H-benzo[3,4-e]thian-6-yl))amino]thioxomethyl \}amino)benzenesulfonamide (15h). The sulfonamide was prepared from $24(1.0 \mathrm{mmol})$ and 4-isothiocyanatobenzenesulfonamide (218 mg, $1.02 \mathrm{mmol}$ ). Recrystallization (95\% EtOH) gave $\mathbf{1 5 h}(252 \mathrm{mg}, 56 \%)$ as a white solid: $\mathrm{mp} 190-192^{\circ} \mathrm{C}$; IR (KBr) 3366, 3267, 1346, 1161 $\mathrm{cm}^{-1}$; ${ }^{1} \mathrm{H}$ NMR $\delta 1.31(\mathrm{~s}, 6 \mathrm{H}), 1.37(\mathrm{~s}, 6 \mathrm{H}), 1.90(\mathrm{~s}, 2 \mathrm{H}), 2.15$ $(\mathrm{s}, 3 \mathrm{H}), 6.93(\mathrm{~s}, 1 \mathrm{H}), 7.23(\mathrm{~s}, 1 \mathrm{H}), 7.35(\mathrm{~d}, \mathrm{~J}=3.57 \mathrm{~Hz}, 2 \mathrm{H})$, $7.68(\mathrm{~d}, \mathrm{~J}=8.79 \mathrm{~Hz}, 2 \mathrm{H}$ ), $9.53(\mathrm{bs}, 1 \mathrm{H}), 9.92$ (bs, $1 \mathrm{H}), 10.02$ (bs, $1 \mathrm{H}$ ); ${ }^{13} \mathrm{C}$ NMR ppm 17.11, 31.20, 32.40, 35.84, 41.94, 53.42, $122.02,122.61,122.77,126.02,126.37,128.66,129.84,132.51$, 134.53, 139.95, 180.09. Anal. $\left(\mathrm{C}_{21} \mathrm{H}_{27} \mathrm{~N}_{3} \mathrm{O}_{2} \mathrm{~S}_{3}\right) \mathrm{C}, \mathrm{H}, \mathrm{N}, \mathrm{S}$

2,2,4,4-Tetramethyl-6-nitrothiochroman (17). The following procedure gave a more pure sample of $\mathbf{1 7}$ over that reported. ${ }^{\text {gb }}$ To a solution of thiochroman ${ }^{16^{10 a}}$ (15.00 g, 72.7 $\mathrm{mmol}$ ) in freshly distilled $\mathrm{Ac}_{2} \mathrm{O}(14 \mathrm{~mL})$ at $-5{ }^{\circ} \mathrm{C}$ (ice/salt) was added dropwise a mixture of cold, concentrated $\mathrm{HNO}_{3}(5.21$ $\mathrm{mL})$ and $\mathrm{Ac}_{2} \mathrm{O}(12.20 \mathrm{~mL}$ ) over $10 \mathrm{~min}$. After being stirred at $-5{ }^{\circ} \mathrm{C}$ for $90 \mathrm{~min}$, the reaction mixture was poured into a solution of saturated, aqueous $\mathrm{NaHCO}_{3}(140 \mathrm{~mL})$, and the resulting emulsion was extracted $\left(\mathrm{H}_{2} \mathrm{CCl}_{2} ; 3 \times 83 \mathrm{~mL}\right)$. The combined organic extracts were washed with $\mathrm{H}_{2} \mathrm{O}(45 \mathrm{~mL})$ and brine $(45 \mathrm{~mL})$ and were then dried $\left(\mathrm{Na}_{2} \mathrm{SO}_{4}\right)$. Evaporation of the solvent gave a dark brown liquid, which was subjected to flash chromatography [hexanes:EtOAc (3:1)] to provide $\mathbf{1 7}^{9 \mathrm{~b}}$ $(4.80 \mathrm{~g}, 26 \%)$ as a light yellow solid: $\mathrm{mp} 105-108^{\circ} \mathrm{C}$ (lit ${ }^{9 b} 103-$ $\left.107^{\circ} \mathrm{C}\right)$; IR (KBr) 1519, $1345 \mathrm{~cm}^{-1}$; ${ }^{1} \mathrm{H} N \mathrm{NMR} \delta 1.45(\mathrm{~s}, 6 \mathrm{H})$, $1.46(\mathrm{~s}, 6 \mathrm{H}), 2.00(\mathrm{~s}, 2 \mathrm{H}), 7.21(\mathrm{~d}, \mathrm{~J}=8.01 \mathrm{~Hz}, 1 \mathrm{H}), 7.88$ (dd, $\mathrm{J}=7.01,2.03 \mathrm{~Hz}, 1 \mathrm{H}), 8.26(\mathrm{~d}, \mathrm{~J}=2.01 \mathrm{~Hz}, 1 \mathrm{H}) ;{ }^{13} \mathrm{C} N M R$ ppm 31.64, 32.43, 35.85, 43.04, 53.24, 120.90, 122.10, 128.15, 131.51, 143.09, 143.48. The nitro compound 17 was used immediately to prepare $\mathbf{1 8}$

2,2,4,4-Tetramethyl-6-aminothiochroman (18). The following procedure gave a more pure sample of $\mathbf{1 8}$ compared to that reported. ${ }^{9 \mathrm{~b}}$ A mixture of $17^{9 \mathrm{~b}}(5.40 \mathrm{~g}, 21.5 \mathrm{mmol})$, iron powder $(0.850 \mathrm{~g}, 15.2 \mathrm{mmol}$, Sigma-Aldrich Chemical Co.) glacial acetic acid $(1.80 \mathrm{~g}, 30 \mathrm{mmol})$, and absolute EtOH (11 $\mathrm{mL}$ ) was stirred at reflux for $12 \mathrm{~h}$. The reaction was allowed to cool to room temperature and was poured into $\mathrm{H}_{2} \mathrm{O}(45 \mathrm{~mL})$, and the resulting emulsion was extracted with ether $(2 \times 40$ $\mathrm{mL})$ and $\mathrm{HCCl}_{3}(3 \times 40 \mathrm{~mL})$. The combined organic extracts were washed with $\mathrm{H}_{2} \mathrm{O}(3 \times 40 \mathrm{~mL})$, dried $\left(\mathrm{Na}_{2} \mathrm{SO}_{4}\right)$, and concentrated to give a dark oil. This crude mixture was then dissolved in ether $(30 \mathrm{~mL})$, and the resulting solution was extracted with $2 \mathrm{~N} \mathrm{HCl}(2 \times 30 \mathrm{~mL})$. The acid solution was neutralized with $40 \% \mathrm{Na}_{2} \mathrm{CO}_{3}(\mathrm{pH} \sim 8)$, and the resulting solution was extracted (ether; $2 \times 30 \mathrm{~mL}$ ). The organic extracts were dried $\left(\mathrm{Na}_{2} \mathrm{SO}_{4}\right)$, and the solvent was evaporated to give amine $1^{9 \mathrm{~b}}(0.370 \mathrm{~g}, 42 \%)$ as a tan oil which crystallized upon standing overnight in a freezer and was recrystallized (hexanes) to yield an off white solid: $\mathrm{mp} 58-60{ }^{\circ} \mathrm{C}$ (lit. ${ }^{9 b} \mathrm{mp} 57-$ $\left.59{ }^{\circ} \mathrm{C}\right)$. Spectral data for the product matched reported values, ${ }^{9 b}$ and amine $\mathbf{1 8}$ was used immediately to prepare $\mathbf{1 5 a -}$ e.

4-Methyl-4-(3-methylphenylthio)-2-pentanone (20). To a solution of 3-methylthiophenol $(19,15.00 \mathrm{~g}, 0.121 \mathrm{~mol})$, mesityl oxide $(11.42 \mathrm{~g}, 0.116 \mathrm{~mol})$, and $\mathrm{HCCl}_{3}(47 \mathrm{~mL})$ at $0{ }^{\circ} \mathrm{C}$ was added $0.7 \mathrm{~mL}$ of triethylamine. The cold bath was removed after the addition $(0.25 \mathrm{~h})$ of triethylamine, and the solution was stirred (room temperature, $1 \mathrm{~h}$ ). The resulting clear solution was heated at reflux ( $24 \mathrm{~h})$. The new solution was allowed to cool to room temperature and then was washed with $10 \% \mathrm{NaOH}(2 \times 25 \mathrm{~mL})$. Combined aqueous layers were extracted (ether; $3 \times 25 \mathrm{~mL}$ ). Combined organic extracts were washed with $\mathrm{H}_{2} \mathrm{O}(25 \mathrm{~mL})$ and brine $(25 \mathrm{~mL})$ and then dried $\left(\mathrm{Na}_{2} \mathrm{SO}_{4}\right)$. The solution was filtered and concentrated. The residual oil was vacuum distilled to give $\mathbf{2 0}(23.26 \mathrm{~g}, 87 \%)$ as a pale yellow liquid: bp $112-115^{\circ} \mathrm{C}(0.8 \mathrm{~mm})$; IR (neat) 1710 $\mathrm{cm}^{-1}$; ${ }^{1} \mathrm{H}$ NMR $\delta 1.39(\mathrm{~s}, 6 \mathrm{H}), 2.15(\mathrm{~s}, 2 \mathrm{H}), 2.36(\mathrm{~s}, 3 \mathrm{H}), 2.67$ $(\mathrm{s}, 3 \mathrm{H}), 7.21(\mathrm{~m}, 2 \mathrm{H}), 7.32(\mathrm{~m}, 2 \mathrm{H}) ;{ }^{13} \mathrm{C} N M R$ ppm 21.09, $28.06,32.08,46.86,54.37,128.51,129.95,131.15,134.65$, 138.29, 138.48, 206.98. Ketone $\mathbf{2 0}$ was used immediately to prepare $\mathbf{2 1}$

2,4-Dimethyl-4-(3-methylphenylthio)-2-pentanol (21). To a $3.0 \mathrm{M}$ solution of $\mathrm{MeM} \mathrm{gBr}(80.5 \mathrm{~mL}, 0.241 \mathrm{~mol})$ was added dropwise 20 ( $26.18 \mathrm{~g}, 0.118 \mathrm{~mol})$ in ether $(48 \mathrm{~mL})$. The solution was stirred at room temperature $(6 \mathrm{~h})$ and then was poured slowly onto ice. The resul ting mixture was neutral ized $\left(5 \% \mathrm{H}_{2-}\right.$ $\mathrm{SO}_{4}, \mathrm{pH} \sim 6.5$ ). The ether layer was separated, and the aqueous layer was extracted (ether; $3 \times 50 \mathrm{~mL}$ ). Organic extracts were combined and dried $\left(\mathrm{Na}_{2} \mathrm{SO}_{4}\right)$. Evaporation of the solvent gave a yellow oil, which vacuum distilled to give 21 (23.57 g, 84\%) as a light yellow liquid: bp $110-112{ }^{\circ} \mathrm{C}(0.5 \mathrm{~mm})$; IR (neat) $3325 \mathrm{~cm}^{-1}$; ${ }^{1} \mathrm{H}$ NMR $\delta 1.34(\mathrm{~s}, 6 \mathrm{H}), 1.36(\mathrm{~s}, 6 \mathrm{H}), 1.80(\mathrm{~s}, 2 \mathrm{H})$, $2.36(\mathrm{~s}, 3 \mathrm{H}), 3.54(\mathrm{~s}, 1 \mathrm{H}), 7.19(\mathrm{~m}, 3 \mathrm{H}), 7.39(\mathrm{~m}, 1 \mathrm{H}) ;{ }^{13} \mathrm{C}$ NMR ppm 20.56, 31.47, 32.64, 35.02, 41.88, 54.46, 126.02, $126.79,128.37,132.36,135.59,139.68$. Alcohol 21 was converted at once to 22

2,2,4,4,7-Pentamethylthiochroman (22). To CS 2 (185 mL) was added $\mathrm{AlCl}_{3}(52.6 \mathrm{~g}, 0.39 \mathrm{~mol})$. To the resulting stirred suspension of $\mathrm{AlCl}_{3}$ was added dropwise a solution of $\mathbf{2 1}$ (23.5 $\mathrm{g}, 98.6 \mathrm{mmol})$ in $\mathrm{CS}_{2}(60 \mathrm{~mL})$ at room temperature over 15 min. The resulting suspension was heated at reflux $(10 \mathrm{~h})$ with stirring. After cooling to room temperature, the suspension was poured onto ice, and the resulting mixture was stirred (5 min). This mixture was separated (two layers), and the aqueous layer was extracted (ether; $3 \times 92 \mathrm{~mL}$ ). Organic extracts were combined, washed with $\mathrm{H}_{2} \mathrm{O}(60 \mathrm{~mL})$ and brine $(60 \mathrm{~mL})$, and then dried $\left(\mathrm{Na}_{2} \mathrm{SO}_{4}\right)$. Evaporation of the solvent gave an orange oil which vacuum distilled to give $22(20.2 \mathrm{~g}, 93 \%)$ as a pale yellow oil: bp 97-99 ${ }^{\circ} \mathrm{C}(0.5 \mathrm{~mm}) ;{ }^{1} \mathrm{H}$ NMR $\delta 1.36(\mathrm{~s}, 6 \mathrm{H})$, $1.39(\mathrm{~s}, 6 \mathrm{H}), 1.93(\mathrm{~s}, 2 \mathrm{H}), 2.25(\mathrm{~s}, 3 \mathrm{H}), 6.89(\mathrm{~m}, 2 \mathrm{H}), 7.26(\mathrm{~m}$, $1 \mathrm{H}) ;{ }^{13} \mathrm{C} N M R$ ppm 20.67, 31.58, 32.73, 35.11, 41.97, 54.54, $125.93,126.71,128.28,132.11,135.48,139.57$. Ether 22 was used at once to prepare $\mathbf{2 3}$

2,2,4,4,7-Pentamethyl-6-nitrothiochroman (23). To a solution of thiochroman $22(15.00 \mathrm{~g}, 68.1 \mathrm{mmol})$ in freshly distilled $\mathrm{Ac}_{2} \mathrm{O}(13 \mathrm{~mL})$ at $-5{ }^{\circ} \mathrm{C}$ (ice/salt) was added dropwise a mixture of cold, concentrated $\mathrm{HNO}_{3}(4.88 \mathrm{~mL})$ and $\mathrm{Ac}_{2} \mathrm{O}$ $\left(11.43 \mathrm{~mL}\right.$ ) over $10 \mathrm{~min}$. After being stirred at $-5^{\circ} \mathrm{C}$ for 90 min, the reaction mixture was poured into a solution of saturated, aqueous $\mathrm{NaHCO}_{3}(130 \mathrm{~mL})$, and the resulting emulsion was extracted $\left(\mathrm{H}_{2} \mathrm{CCl}_{2}, 3 \times 78 \mathrm{~mL}\right)$. Combined organic extracts were washed with $\mathrm{H}_{2} \mathrm{O}(42 \mathrm{~mL})$ and brine (42 $\mathrm{mL}$ ) and were then dried $\left(\mathrm{Na}_{2} \mathrm{SO}_{4}\right)$. Evaporation of the sol vent gave a dark brown liquid, which was subjected to flash chromatography [hexanes:EtOAc (3:1)] to provide 23 (4.70 g, $26 \%$ ) as a light yellow solid: $\mathrm{mp} 160-162{ }^{\circ} \mathrm{C}$; IR (KBr) 1516, $1349 \mathrm{~cm}^{-1}$; ${ }^{1 \mathrm{H}} \mathrm{NMR} \delta 1.46(\mathrm{~s}, 6 \mathrm{H}), 1.49(\mathrm{~s}, 6 \mathrm{H}), 2.03(\mathrm{~s}, 2 \mathrm{H})$, $2.64(\mathrm{~s}, 3 \mathrm{H}), 7.78(\mathrm{~s}, 1 \mathrm{H}), 7.97(\mathrm{~s}, 1 \mathrm{H}) ;{ }^{13} \mathrm{C} N M R$ ppm 19.83, $25.98,31.93,34.81,46.27,54.02,122.94,131.33,132.45$, 143.26, 144.33, 150.45. The nitro compound 23 was used immediately to prepare 24

2,2,4,4,7-Pentamethyl-6-aminothiochroman (24). A mixture of $\mathbf{2 3}(5.40 \mathrm{~g}, 20.3 \mathrm{mmol})$, iron powder $(0.802 \mathrm{~g}, 14.3 \mathrm{mmol}$, Sigma-Aldrich Chemical Co.), glacial acetic acid (1.70 g, 28.3 $\mathrm{mmol})$, and absolute EtOH (11 mL) was stirred at reflux (12 h). The reaction was allowed to cool to room temperature and was poured into $\mathrm{H}_{2} \mathrm{O}(42 \mathrm{~mL})$, and the resulting emulsion was extracted with ether $(2 \times 38 \mathrm{~mL})$ and $\mathrm{HCCl}_{3}(3 \times 38 \mathrm{~mL})$. Combined organic extracts were washed with $\mathrm{H}_{2} \mathrm{O}(3 \times 38 \mathrm{~mL})$, dried $\left(\mathrm{Na}_{2} \mathrm{SO}_{4}\right)$, and concentrated to give a dark oil. This crude mixture was then dissolved in ether $(28 \mathrm{~mL})$, and the resulting 
solution was extracted with $2 \mathrm{~N} \mathrm{HCl}(2 \times 28 \mathrm{~mL})$. The acid solution was neutralized $\left(40 \% \mathrm{Na}_{2} \mathrm{CO}_{3}, \mathrm{pH} \sim 8\right)$, and the resulting solution was extracted with ether $(2 \times 28 \mathrm{~mL})$. The combined extracts were dried $\left(\mathrm{Na}_{2} \mathrm{SO}_{4}\right)$, and the solvent was evaporated to afford amine $\mathbf{2 4}(2.16 \mathrm{~g}, 45 \%)$ as a tan oil, which crystallized upon standing overnight in the freezer and was recrystallized (hexanes) to give an off white solid: $\mathrm{mp}$ 61-63 ${ }^{\circ} \mathrm{C}$; IR (KBr) 3459, $3366 \mathrm{~cm}^{-1}$; ${ }^{1} \mathrm{H}$ NMR $\delta 1.34$ (s, $\left.6 \mathrm{H}\right), 1.38$ (s, $6 \mathrm{H}), 1.89(\mathrm{~s}, 2 \mathrm{H}), 2.09(\mathrm{~s}, 3 \mathrm{H}), 6.74(\mathrm{~s}, 1 \mathrm{H}), 6.83(\mathrm{~s}, 1 \mathrm{H}) ;{ }^{13} \mathrm{C}$ NMR ppm 16.60, 31.41, 32.37, 35.25, 41.76, 54.72, 113.63, 121.04, 121.27, 129.98, 141.80, 142.22. Amine 24 was used immediately to prepare $\mathbf{1 5 f}-\mathbf{h}$.

Growth Inhibition Assays. The OVCAR-3, Caov-3, and SK-OV-3 ovarian carcinoma cell lines were obtained from American Type Culture Collection. The OVCAR-3 cultures were maintained in RPMI media supplemented with $10 \%$ fetal bovine serum (FBS). The Caov-3 and SK-OV-3 cultures were maintained in MEM media supplemented with $10 \%$ FBS, nonessential amino acids, sodium pyruvate, antibiotics, and antimycotics (complete MEM). A primary culture of a benign ovarian cyst and one of a borderline ovarian tumor were established from specimens obtained from two consenting patients undergoing surgery at the University of Oklahoma Health Sciences Center. The specimens were cut into two fragments, vortexed vigorously, and plated onto $100 \mathrm{~mm}$ tissue culture dishes containing complete MEM media. Monolayer cultures that developed were passaged once before cryogenic preservation. All experiments were performed on cultures at passages 3 or 4 in which the majority of cells were epithelial. Fibroblasts began to outgrow the epithelial cells after passage 4. Only lots of FBS with undetectable levels $\left(<10^{-8} \mathrm{M}\right)$ of retinol and retinoic acid isomers were used, as determined by high performance liquid chromatography.

All compounds were dissolved in dimethyl sulfoxide (DMSO) and stored as aliquots of $1000 \times$ stock solutions at $-70{ }^{\circ} \mathrm{C}$. Since the retinoids appeared to be slightly light sensitive, all manipulations involving retinoids were performed under subdued lighting. Each experiment included control cultures that received the same volume of DMSO solvent that was administered in the treatment. The concentration of DMSO in each experiment was always equal to or less than $0.01 \%$, a concentration which was not toxic and which did not induce differentiation.

Cultures were plated in 96-well microtiter plates in volumes of $150 \mu \mathrm{L}$ at a concentration of 1000 cells/well. The following day, retinoids were added at $4 \times$ concentrations in $50 \mu \mathrm{L}$ of media resulting in final concentrations of $1,4,7$, and $10 \mu \mathrm{M}$ of each compound. After 3 days of treatment, the number of living cells was quantitated using the MTS [3-(4,5-dimethylthiazol-2-ol)-5-(3-carboxymethoxyphenyl)-2H-tetrazolium inner salt] assay (Promega Life Science, Madison WI). Metabolically active cells reduce the MTS compound to an aqueous soluble formazan, resulting in an absorbance measurable at $490 \mathrm{~nm}$ (Promega Technical Bulletin No.169). A mixture of MTS solution and PMS (phenazine methosulfate) in Dulbecco's phosphate-buffered saline was added to each well. The plate was wrapped with foil and shook at $180 \mathrm{rpm}$ for $5 \mathrm{~min}$ on an orbital shaker (Fisher Scienctific, Hanover Park, IL) before incubating at $37{ }^{\circ} \mathrm{C}$ in $5 \% \mathrm{CO}_{2}$. The plate was removed at various intervals, shook for $5 \mathrm{~min}$, and then read at $\mathrm{OD}_{490}$ on a microtiter plate reader until the readings were in the linear range (0.1-0.6). Each experiment was performed in triplicate, and the three values for each treatment were averaged. To determine the percent growth inhibition, the average OD of the untreated cultures was divided by the average OD of the control cultures treated with solvent alone and multiplied by 100.

Measurements of Reactive Oxygen Species (ROS). Marker 5-(and 6-)carboxy-2',7'-dichlorodihydrofluorescein diacetate (carboxy-H2DCFDA) was obtained from Molecular Probes (Eugene, OR), and 96-well black isoplates were obtained from Perkin-Elmer Life Sciences (Boston, MA). Cells were plated in 96-well black isoplates and treated with the compounds. After the treatment interval, cells underwent serial washes with assay buffer by centrifugation. The assay buffer contained $10 \mu \mathrm{M}$ glucose, $1 \mu \mathrm{M}$ calcium chloride, and 2 $\mu \mathrm{M}$ magnesium chloride. Carboxy-H2DCFDA ( $50 \mu \mathrm{M})$ was then added, and the assay for ROS production was initiated as previously described. ${ }^{26}$ Fluorescence was measured on a Wallace Victor-2 96-well plate reader (excitation at $485 \mathrm{~nm}$ and emission at $538 \mathrm{~nm}$ ).

Retinoic Acid Receptor Activation. The activation of endogenous receptors in cancer cells was evaluated as previously described. $.9 b, c, 27$ Briefly, cultures of SW962 cells and CC-1 cells that had been previously transfected with RARE-RAR $\beta$ tk-CAT reporter plasmid were treated with $\mathbf{1 5 a}-\mathbf{c}, 9-\mathrm{c}-\mathrm{RA}$ (positive control), or the same volume of control solvent (DMSO-negative control) at concentrations of $10^{-9}, 10^{-8}, 10^{-7}$, $10^{-6}$, and $10^{-5} \mathrm{M}$ for $48 \mathrm{~h}$. Activation of the endogenous receptors in the SW962 and CC-1 cell lines was determined by measuring the level of CAT (chloramphenicol acetyl transferase) protein present in each treated and untreated culture. The ability of these compounds and concentrations to activate each individual retinoic acid receptor (RAR) and retinoic $X$ receptor (RXR) were evaluated as previously cited. ${ }^{9 b, 9 c}$

Acknowledgment. We gratefully acknowledge partial support of this work by the National Institutes of Health through grants from the National Cancer Institute (CA-73639 and F3CA83168), through the NRSAFellowship (IF 31 CA83168 to C.W.B.) from the National Cancer Institute, and the National Cancer Institute (CA-077711 to D.M.B.). Special thanks is also extended to the National Institutes of Health and the Oklahoma State University Department of Biochemistry and Molecular Biology for early support from the Minorities in Biomedical Research Fellowship (5 R25 GM 55244-02 to C.W.B.). In addition, we are pleased to acknowledge funding for the Varian I nova $400 \mathrm{MHz}$ NMR spectrometer in the Oklahoma Statewide Shared NMR Facility by the National Science F oundation (BIR-9512269), the Oklahoma State Regents for Higher Education, the W. M. Keck Foundation, and Conoco, Inc. Salary support (K.D.B.) by the College of Arts and Sciences is gratefully acknowledged.

\section{References}

(1) (a) Sporn, M. B.; Roberts, A. B. The Retinoids-Biology, Chemistry and Medicine, 2nd ed:; Raven Press Ltd: New York, 1994. (b) Dawson, M. I. Burger's Medicinal Chemistry and Drug Discovery, 5th ed.; Wolff, M. E., Ed.; J ohn Wiley \& Sons: New York, 1996; pp 576-616. (c) Alberts, D. S.; Colvin, D. M.; Conney, A. H.; Ernster, V. L.; Garber, J . E.; Greenwald, P.; Gudas, L.j .; Hong W. K.; Kelloff, G. J .; Kramer, R. A.; Lerman, C. E.; Manglesdorf, D. J.; Matter, A.; Minna, J . D.; Nelson V, W. G.; Pezzuto, J . M.; Prendergast, F.; Rusch, V. W.: Sporn, M. B.; Wattenberg, L. W.; Weinstein, I. B. Prevention of Cancer in the Next MillenniumReport of the Chemoprevention Working Group to the American Association for Cancer Research. Cancer Res. 1999, 59, 47434758. (d) Gale, J. B. Progress of Medicinal Chemistry; Ellis, G. P., Luscombe, D. K., Eds.; Elsevier Science B. V.: Amsterdam, 1993; Vol. 30, pp 1-55. (e) Nagpal, S.; Chandrarantna, R. A. S Retinoids as Anticancer Agents. Curr. Pharm. Des. 1996, 2, 295316. (f) The biology of heteroarotinoids has been reviewed; see Benbrook, D. M. Refining Retinoids with Heteroatoms. Mini Rev. Med. Chem. 2002, 2, 277-283.

(2) (a) See (1a), pp 319-321. (b) See (1b), p 579. (c) Benbrook, D. M.; Subramanian, S.; Gale, J . B.; Liu, S.; Brown, C. W.; Boehm, M. F.; Berlin, K. D. Synthesis and Characterization of Heteroarotinoids Demonstrates Structure-Activity Relationships. J Med. Chem. 1998, 41, 3753-3757. (d) J ong, L.; Lehmann, J . M.; Hobbs, P. D.; Harlev, E.; Huffman, J . C.; Pfahl, M.; Dawson, M. I. Conformatinal Effects on Retinoid Receptor Selectivity. 1. Effect of the 9-Double Bond Geometry. on Retinoid X Receptor Activity. J . Med. Chem. 1993, 36, 2605-2613. (e) Lehmann, J . M.; J ong, L.; Fanjul, A.; Cameron, J . F.; Lu, X. P.; Haefner, P. Dawson, M. I.; Pfahl, M. Retinoids Selective for Retinoid X Receptor Response Pathways. Science 1992, 258, 1944-1946.

(3) (a) See ref 1a, pp 322-323. (b) See ref 1b, pp 579-583. (c) Giguere, V. M.; Shago, R.; Zirngibl, P.; Tate, P.; Rossant, J .; Varmuza, S. Identification of a Novel Isoform of the Retinoic 
Acid Receptor Gamma Expressed in the Mouse Embryo. Mol Cell. Biol. 1990, 10, 2335-2340. (d) Giguere, V.; Ong, E. S.; Segui, P.; Evans, R. M. Identification of a New Class of Steroid Hormone Receptors. Nature 1987, 330, 624-629.

(4) (a) See ref $1 a$, pp 323-324. (b) See ref 1b, pp 579-583. (c) Manglesdorf, D. J .; Borgmeyer, U.; Heyman, R. A.; Zhou, J . Y. Ong, E. S.; Oro, A. E.; Kakizuka, A.; Evans, R. M. Characterization of Three RXR Genes That Mediate The Action of 9-cisRetinoic Acid. Genes Dev. 1992, 6, 329-344. (d) Leid, M.; Kastner, P.; Lyons, R.; Nakshatri, H.; Saunders, M.; Zacharewski, T.; Chen, J.-Y.; Staub, A.; Garnier, J.-M.; Mader, S.; Chambon, P. Purification, Cloning, and RXR Identity of the HeLa Cell Factor With Which RAR or TR Heterodimerizes to Bond Target Sequences Efficiently. Cell 1992, 68, 377-395.

(5) Hong, W. K.; Sporn, M. B. Recent Adances in Chemoprevention of Cancer. Science 1997, 278, 1073-1077.

(6) (a) See ref 1a, pp 597-605. (b) See ref 1b, pp 590-600

(7) (a) See ref 1a, pp 550-566. (b) See ref 1b, pp 600-604. (c) Lehmann, J . M.; J ong, L.; Fanjul, A.; Cameron, J . F.; Lu, X. P.; Haefner, P.; Dawson, M. I.; Pfahl, M. Retinoids Selective for Retinoid X Receptor Response Pathways. Science 1992, 258, 1944-1946.

(8) Rizvi, N. A.; Marshall, J. L.; Dahut, W.; Ness, E.; Ztruglia, J . A.; Loewen, G.; Gill, G. M.; UIm, E. M.; Geiser, R.; J uanakais, D.; Hawkins, M. J . A Phase I Study of LDG1069 in an Adult With Advanced Cancer. Clin. Cancer Res. 1945, 5, 1658-1664.

(9) (a) Guruswamy, S.; Lightfoot, S.; Gold, M.; Hassan, R.; Berlin, K. D.; I vey, T. R.; Benbrook, D. M. Effects of Retinoids on Cancer Phenotype and Apoptosis in Organotypic Culture of Ovarian Carcinoma. J . Natl. Cancer Inst. 2001, 93, 516-525. (b) Zacheis, D.: Dhar, A.; Lu, S.; Madler, M. M.; Klucik, J .; Brown, C. W.; Liu, S.; Clement, F.; Subramanian, S.; Weerasekare, G. M.; Berlin, K. D.; Gold, M. A.; Houck, J. R.; Fountain, K. R.; Benbrook, D. M. Heteroarotinoids I nhibit Head and Neck Cancer Cell Lines in Vitro and in Vivo Through Both RAR and RXR Retinoic Acid Receptors. J. Med. Chem. 1999, 42, 4434-4445. (c) Dhar, A.; Liu, S.; Klucik, J .; Berlin, K. D.; Madler, M. M.; Lu, S.; Ivey, R. T.; Zacheis, D.; Brown, C. W.; Nelson, E. C.; Birckbichler, P. J .; Benbrook, D. M. Synthesis, StructureActivity Relationships, and RAR $\gamma$-Ligand Interactions of Nitrogen Heteoarotinoids. J. Med. Chem. 1999, 42, 3602-3614. (d) Benbrook, D. M.; Subramanian, S.; Glae, J . B.; Liu, S.; Brown, C. W.; Boehm, M. F.; Berlin, K. D. Synthesis and Characterization of Heteroarotinoids Demonstrate Structure Specificity Relationships. J. Med. Chem. 1998, 41, 3753-3757. (e) Benbrook, D. M.; Madler, M. M.; Spruce, L. W.; Birckbichler, P. J .; Nelson, E. C.; Subramanian, S.; Weerasekare, G. M.; Gale, J. B.; Patterson, M. K., J r.; Wang, B.; Wang, W.; Lu, S.; Rowland, T.: DiSivestro, P.: Lindamood, C., III; Hill, D. L.; Berlin, K. D. Biologically Active Heteroarotinoids Exhibiting Anticancer Activity and Decreased Toxicity. J. Med. Chem. 1997, 40, 35673583. (f) See ref 1a, pp 110-128.

(10) (a) Spruce, L. W.; Gale, J . B.; Berlin, K. D.; Verma, K. A.; Breitman, T. R.; J i, X.; van der Helm, D. Novel Heteroarotinoids: Synthesis and Biological Activity. J . Med. Chem. 1991, 34, 430-439. (b) Spruce, L. W.: Rajadhyaksha, S. N.: Berlin, K. D.; Gale, J . B.; Miranda, E. T.; Ford, W. T.; Blossey, E. C.; Verma, A. K.; Hossain, M. B.; van der Helm, D.; Breitman, T. R. Heteroarotinoids. Synthesis, Characterization, and Biological Activity in Terms of an Assessment of These Systems to I nhibit Induction of Ornithine Decarboxylase Activity and to Induce Terminal Differentiation of HL-60 Cells. J . Med. Chem. 1987, 30, 1474-1482. (c) Waugh, K. M.; Berlin, K. D.; Ford, W. T. Holt, E. M.; Carroll, J . P.; Schomber, P. R.; Schiff, L.J . Synthesis and Characterization of Selected Hetero-arotinoids. Pharmacological Activity as Assessed in Vitamin A Deficient Hamster Tracheal Organ Cultures. Single-Crystal X-ray Diffraction Analysis of 4,4-Dimethylthiochroman-6-yl Methyl Ketone 1,1-Dioxide sand Ethyl (E)-4-[2-(4,4-Dimethylthiochroman-6-yl)-1-propenyl]benzoate. J. Med. Chem. 1985, 27, 116-124. (d) Benbrook, D. M. Refining Retinoids with Heteroatoms. Mini Rev. Med. Chem. 2002, 2, 277-283.

(11) (a) One arotinoid with a urea linker has been recorded; see: Takagi, K.; Suganuma, M.; Kagechika, H.; Shudo, K.; Ninomiya, M.; Muto, Y.; Fujiki, H. Inhibition of Ornithine Decarboxylase Induction by Retinobenzoic Acids in Relation to Their Binding Affinities to Cellular Retinoid-Binding Proteins. J. Cancer Res. Clin. Oncol. 1988, 114, 221-224. (b) For a review on three- or more-atom linker groups in retinoids, see ref $1 a$, pp 128-140.
(12) Klaholz, B. P.; Mitschler; Moras, D. Structural Basis for I sotope Selectivity of the Human Retinoic Acid Nuclear Receptor. J . Mol. Biol. 2000, 302, 155-170.

(13) Bernard, B. A.; Bernardon, J .-M.; Delescluse, C.; Martin, B.; Lenoir, M.-C.; Maigan, J .; Charpentier, B.; Pilgrim, W. R.; Reichert, U.; Shroot, B. I dentification of Synthetic Retinoids with Selectivity for Human Nuclear Retinoic Acid Receptor Gamma. Biochem. Biophys. Res. Commun. 1992, 186, 977-983.

(14) (a) Klaholz, B. P.; Mitschler, A.; Belema, M.; Zusi, C.; Moras, D. Enantiomer Discrimination Illustrated by High-Resolution Crystal Structures of the Human Nuclear Receptor hRAR $\gamma$. Proc Natl. Acad. Sci. U.S.A. 2000, 97, 6322-6327. (b) Gehin, M.; Vivat, V.; Wurtz, J.-M.; Losson, R.; Chambon, P.; Moras, D.; Gronemeyer, H. Structural Basis for Engineering of Retinoic Acid Receptor I sotope-Selective Agonists and Antagonists. Chem. Biol. 1999, 6, 519-529. (c) Yu, K.-L.; Spinazze, P.; Ostrowski, J .; Currier, S. J .; Pack, E. J .; Hammer, L.; Roalsvig, T.; Honeyman, J. A.; Tortolani, D. R.; Reczek, P. R.; Mansuri, M. M.; Starrett, J . E., J r. Retinoic Acid Receptor Beta, GammaSelective Ligands: Synthesis and Biological Activity of 6-Substituted 2-Naphthoic Acid Retinoids. J . Med. Chem. 1996, 39, 2411-2421.

(15) Morriss-Kay, G. M.; Sokolova, N. Embryonic Development and Pattern Formation. FASE B J . 1996, 10, 961-968.

(16) Kato, S.; Mano, H.; Kumazawa, T.; Yoshizawa, Y.; Kojima, R.; Masushige, S. Effect of Retinoid Status on Alpha, Beta, and Gamma Retinoic Acid Receptors mRNA in Various Rat Tissues. Biochem. J . 1992, 286, 755-760.

(17) Fanjul, A. N.; Delia, D.; Pierotti, M. A.; Dideout, D.; Yu, J. Q.; Pfahyl, M.; Yu, J . Q. 4-Hydroxyphenyl-retinamide is a Highly Selective Activator of Retinoid Receptors. J . Biol. Chem. 1996, 271, 22441-22446.

(18) Sparks, A. K. Solvents Effects in Aromatic Nitration. Nitration by Acyl Nitrates. J . Org. Chem. 1966, 31, 2299-2302.

(19) Owsley, D. C.; Bloomfield, J . J . The Reduction of Nitroarenes With Iron/ Acetic Acid. Synth. Comm. 1977, 118-120.

(20) Renauld, J. P.: Rochel, N.; Ruff, M.; Vivat, V.; Chambon, P . Gronemeyer, H.; Moras, D. Crystal Structure of the RAR- $\gamma$ Ligand-Binding Domain Bound to all-trans-Retinoic Acid. Nature 1995, 378, 681-689.

(21) Chun, K.-H.; Benbrook, D. M.; Berlin, K. D.; Honk, W. K.; Lotan, R. Induction of Apoptosis in Head and Neck Squamous Cell Carcinoma (HNSCC) Cell Lines by Heteroarotinoids Through a Mitochondrial Dependent Pathway. Cancer Res. 2003, 63, 38283832.

(22) (a) Clifford, J . L.; Menter, D.; Wang, M.; Lotan, R.; Lipman, S. $M$. Retinoid Receptor-Dependent and Independent Effects of $\mathrm{N}$-(4-Hydroxyphenyl)retinamide in $\mathrm{F} 9$ Embryonal Carcinoma Cells. Cancer Research 1999, 59, 14-18. (b) Oridate, N.; Lotan, D.; Xu, X.-C.; Hong, W.; Lotan, R. Differential Induction of Apoptosis by all-trans-Retinoic Acid and N-(4-Hydroxyphenyl)retinamide in Human Head and Neck Squamous Cell Carcinoma Cell Lines. Clin. Cancer Res. 1996, 2, 855-863.

(23) Kamelle, S. A.; Guruswamy, S. B.; Lightfoot, S. A.; Rutlege, T. L.; Gould, N. S.; Dunn, S. T.; Berlin, K. D.; Benbrook, D. M. Receptor-Active and Receptor-Independent Retinoids Regulate Growth, Differentiation, and Apoptosis in Ovarian Cancer Xenographs. Unpublished results.

(24) Unpublished results, Benbrook, D. M.; Berlin, K. D.

(25) Brown, C. W.; Liu, S.; Klucik, J .; Berlin, K. D.; Brennan, P.J .; Kaul, D.; Benbrook, D. M. Novel Heteroarotinoids as Potential Antagonists of Mycobacterium bovis BCB. J . Med. Chem. 2003, 46, XXXX (following paper in this issue).

(26) Suzuki, S.; Highuchi, M.; Proske, R. J .; Oridate. N.; Hong, W. K.; Lotan, R. Implication of Mitochondria-Derived Reactive Oxygen Species, Cytochrome a, and Caspase-3, in N-(4-Hydroxyphenyl)retinamide-Induced Apoptosis in Cervical Carcinoma Cells. Oncogene 1999, 18, 6380-6387.

(27) Benbrook, D. M.; Lu, S.; Flanagan, C.; Shen-Gunther, J .; Angros, L. H.; Lightfoot, S. A. Biological Assay for Activity and Molecular Mechanism of Retinoids in Cervical Tumor Cells. Gyn. Oncol. 1997, 66, 114-121.

\section{J M030346V}

